\title{
Multi-disciplinary investigation of the tomb of Menna (TT69), Theban Necropolis, Egypt
}

\author{
Peter Vandenabeele ${ }^{\mathrm{a}, *}$, Renata Garcia-Moreno ${ }^{\mathrm{b}}$, François Mathis ${ }^{\mathrm{b}}$, \\ Kerstin Leterme $^{\mathrm{a}, \mathrm{b}}$, Elsa Van Elslande ${ }^{\mathrm{c}}$, François-Philippe Hocquet ${ }^{\mathrm{b}}$, \\ Saïd Rakkaa ${ }^{\mathrm{b}}$, Dimitri Laboury ${ }^{\mathrm{b}}$, Luc Moens ${ }^{\mathrm{d}}$, David Strivay ${ }^{\mathrm{b}}$, Melinda Hartwige \\ ${ }^{a}$ Ghent University, Department of Archaeology and Ancient History of Europe, Blandijnberg 2, B-9000 Ghent, Belgium \\ b University of Liège, Centre Européen d'Archéométrie, Institut de Physique Nucléaire, Atomique et de Spectroscopie, Allée du 6 Août, bât. B15, B-4000 Liège, Belgium \\ ${ }^{c}$ Centre de Recherche et de Restauration des Musées de France (C2RMF), CNRS UMR 171, Palais du Louvre, Porte des Lions, 14 Quai François Mitterrand, F-75001 Paris, France \\ d Ghent University, Department of Analytical Chemistry, Proeftuinstraat 86, B-9000 Ghent, Belgium \\ e Georgia State University, Ernest G. Welch School of Art and Design,10 Peachtree Center Avenue, Art E' Humanities Building, Atlanta, GA 30302-4107, USA
}

\section{A R T I C L E I N F O}

\section{Article history:}

Received 27 June 2008

Accepted 10 July 2008

\section{Keywords:}

Archaeometry

Egyptian wall paintings

Tomb of Menna (TT69)

Raman spectroscopy

$\mathrm{X}$-ray fluorescence (XRF)

UV-vis spectroscopy

IR-spectroscopy

Mobile equipment

In situ analysis

\begin{abstract}
A B S T R A C T
The archaeometrical survey of the tomb of Menna (TT69), which took place in November-December 2007, is part of the extended research program that aims to study and preserve this tomb in all its aspects. Menna was a high official who served as an overseer of Cadastral surveys during the reigns of pharaohs Tuthmosis IV and Amenhotep III (са. 1419-1370 вс). The research team aimed to gather information, in a totally nondestructive way, on the materials used and the painting techniques. The technical examinations included photography with normal and raking light, macrophotography, ultra-violet (UV) fluorescence photography, and microscopy. On selected points X-ray fluorescence (XRF) was combined with diffuse reflectance UV-spectrometry, near infrared (NIR) diffuse reflectance spectroscopy and Raman spectroscopy. The technical aspects as well as problems that are inherently associated with an interdisciplinary survey of this extent, are discussed. The project worked with a large team of people with different backgrounds and sensitive technical equipment. Working conditions were quite hostile, including elevated temperatures and dust hampering the examinations.
\end{abstract}

(C) 2008 Elsevier B.V. All rights reserved.

\section{Introduction}

Ancient Egyptian culture is often considered as one of the sources of western civilisation. The society lasted for over 3000 years and is well known for its monumental constructions. In many museums worldwide, pharaonic material such as sarcophagi, statuary, relief, painting, papyri and daily life objects can be found, and originate from temple, tomb or pyramid contexts. Several aspects of Egyptian painting techniques have been studied on these objects. However, when studying the painting technique and materials of Egyptian wall paintings, one has to rely on photos, ancient texts, and/or samples, and on-site investigations. In the past, many research papers have been published on ancient Egyptian painting, and based their methodology on the style or iconography of these paintings. In the past, several technical examinations, including Raman spectroscopy, have

\footnotetext{
* Corresponding author. Tel.: +32 926466 23/36 42; fax: +32 92646699 E-mail address: peter.vandenabeele@UGent.be (P. Vandenabeele).
}

been applied on antique Egyptian objects, usually in a museum context [1-9]. The current research paper reports on the first extensive in situ archaeometric survey of ancient Egyptian tomb painting with the goal of ascertaining their materials, transformations and artistic techniques. The Egyptian government has strictly forbidden the export of samples out of the country, so the investigations were performed on site in a totally non-destructive way.

The subject of this study is the tomb of Menna (TT69), located on the Theban Necropolis (Luxor, Egypt), a private 18th dynasty tomb chapel, which was constructed and decorated at some point during the reigns of pharaohs Tuthmosis IV and Amenhotep III (ca. 1419-1370 вс). The Tomb of Menna (TT69) Conservation and Documentation Project aims to study, document and publish the archaeology, architecture and decoration of this tomb, and to ensure its conservation. The aims of this project are multiple:

- to prove that mobile analytical techniques can be used for the non-destructive examination of ancient Egyptian wall paintings-even under harsh conditions; 
Table 1

Summary of the identified pigments in the tomb of Menna.

\begin{tabular}{|c|c|c|c|c|c|}
\hline Colour & Pigment & Formula & $\mathrm{XRF}^{\mathrm{a}}$ & Raman $^{\text {b }}$ & UV-vis-NIR ${ }^{\mathrm{b}}$ \\
\hline White & $\begin{array}{l}\text { Calcite } \\
\text { Gypsum }\end{array}$ & $\begin{array}{l}\mathrm{CaCO}_{3} \\
\mathrm{CaSO}_{4} \cdot 2 \mathrm{H}_{2} \mathrm{O}\end{array}$ & $\begin{array}{l}\mathrm{Ca} \\
\mathrm{Ca}, \mathrm{S}\end{array}$ & $\begin{array}{l}\sqrt{ } \\
\sqrt{ }\end{array}$ & $\begin{array}{l}\times \\
\sqrt{ }\end{array}$ \\
\hline Red & $\begin{array}{l}\text { Red ochre/iron oxide } \\
\text { Realgar }\end{array}$ & $\begin{array}{l}\mathrm{Fe}_{2} \mathrm{O}_{3} \\
\mathrm{As}_{4} \mathrm{~S}_{4}\end{array}$ & $\begin{array}{l}\mathrm{Fe} \\
\text { As, } \mathrm{S}\end{array}$ & $\begin{array}{l}\sqrt{ } \\
\sqrt{ }\end{array}$ & $\begin{array}{l}\sqrt{ } \\
\times\end{array}$ \\
\hline Yellow & $\begin{array}{l}\text { Yellow ochre/iron hydroxide } \\
\text { Orpiment }\end{array}$ & $\begin{array}{l}\mathrm{FeOOH} \\
\mathrm{As}_{2} \mathrm{~S}_{3}\end{array}$ & $\begin{array}{l}\mathrm{Fe} \\
\text { As, S }\end{array}$ & $\begin{array}{l}\times \\
\sqrt{ }\end{array}$ & $\begin{array}{l}\sqrt{ } \\
\sqrt{ }\end{array}$ \\
\hline $\begin{array}{l}\text { Blue } \\
\text { Green } \\
\text { Black }\end{array}$ & $\begin{array}{l}\text { Egyptian blue } \\
\text { Egyptian blue + orpiment } \\
\text { Carbon black }\end{array}$ & $\begin{array}{l}\mathrm{CaCuSi}_{4} \mathrm{O}_{10} \\
\mathrm{CaCuSi}_{4} \mathrm{O}_{10}+\mathrm{As}_{2} \mathrm{~S}_{3} \\
\mathrm{C}\end{array}$ & $\begin{array}{l}\mathrm{Cu}, \mathrm{Ca} \\
\mathrm{Cu}, \mathrm{Ca}, \mathrm{As}, \mathrm{S}\end{array}$ & $\begin{array}{l}x^{c} \\
x^{c} \\
\sqrt{ }\end{array}$ & $\begin{array}{l}\sqrt{ } \\
\sqrt{ } \\
\times\end{array}$ \\
\hline
\end{tabular}

a The element indicates which key-element could be identified for this pigment

b $\sqrt{ }$ and $x$ indicate whether a spectrum could be obtained or not, respectively.

c Fluorescence made it impossible to record a Raman spectrum.

- to study the painting materials that were used during the production of this tomb chapel;

- to obtain information on the artistic techniques and workshop organisation.

To address these project aims, a multi-disciplinary archaeometrical team was assembled, consisting of physicists, chemists, conservators, Egyptologists, art historians and engineers, working collaboratively to reach these goals. The techniques were selected to provide complementary information. Visual inspection and macrophotography under normal and ranking light, with the naked eye, under magnification, and with UV light, were usually the first steps in this study [10]. Selected points were investigated by means of Raman spectroscopy, X-ray fluorescence (XRF) analysis, diffuse reflectance ultra-violet-visible (UV-vis) spectroscopy, and diffuse reflectance near infrared spectroscopy. To our best knowledge, this
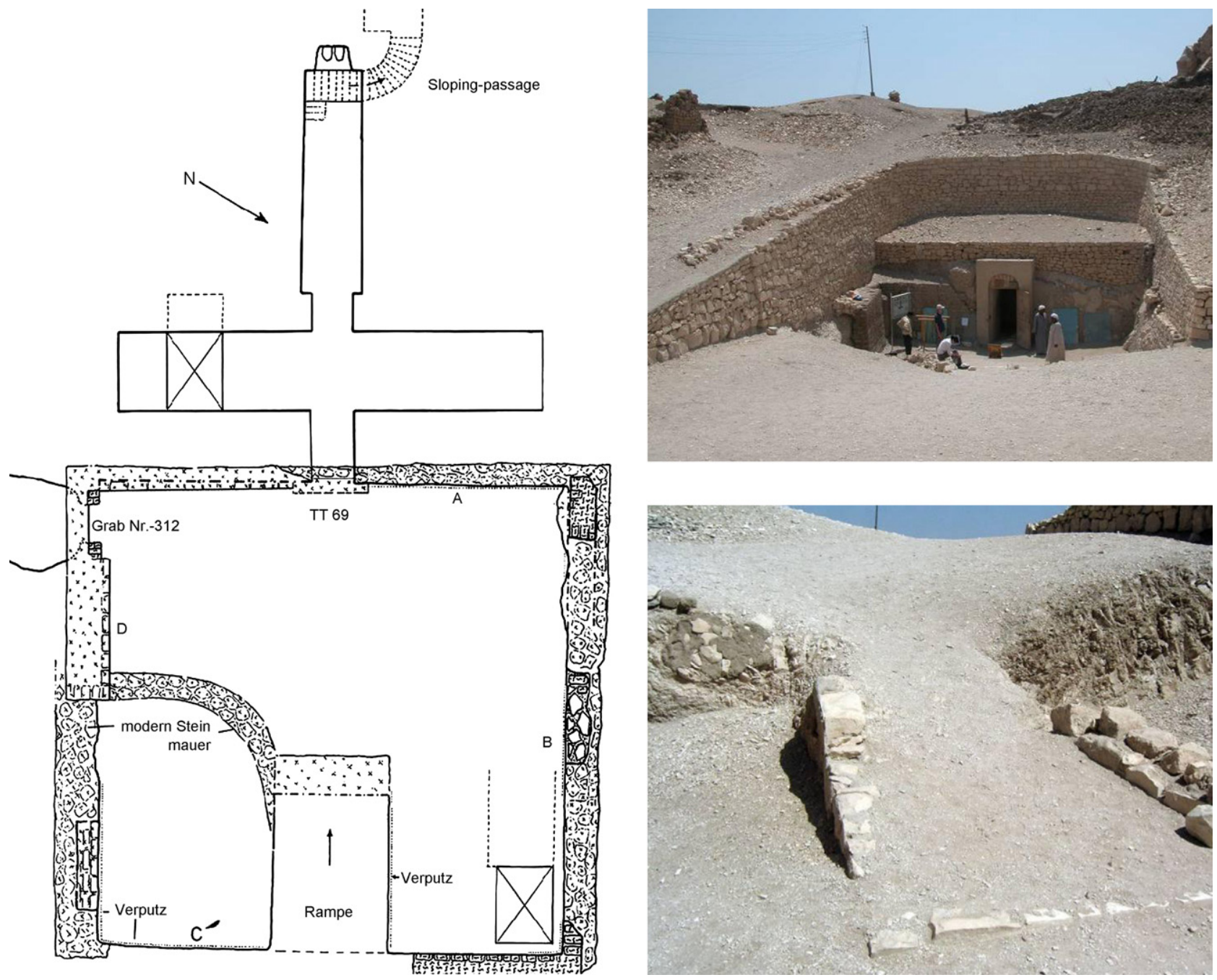

Fig. 1. Ground plan and pictures of the tomb of Menna (TT69). 

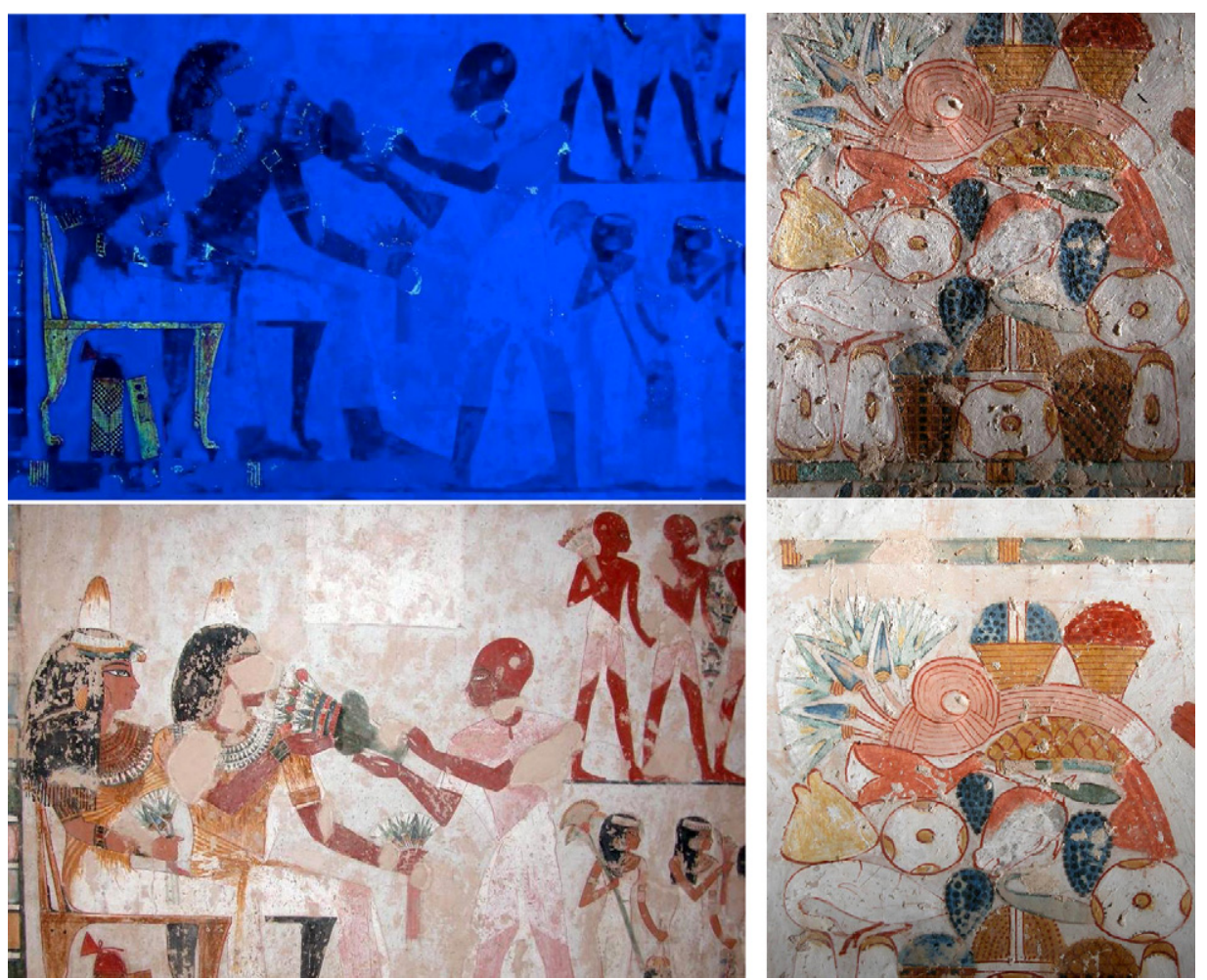

Fig. 2. UV-fluorescence and ranking light pictures of parts of the wall paintings from the tomb of Menna (TT69), along with the corresponding vis pictures.

is the first time that such an elaborate on-site investigation with non-destructive techniques was performed in Egypt.

\section{The tomb of Menna (TT69)}

The tomb of Menna was never finished, yet remains one of the most completely painted Theban tombs. Its painting is exceptionally rendered and has been the focus of study for art historians and Egyptologists since the beginning of the last century. The tomb of Menna (TT69) was originally cleared by Robert Mond in 1905 for the Antiquities Service [11,12] and its decorative program was briefly treated by Cambell [13] and again by Maher-Taha [14]. The tomb is composed of a inverted T-shape chapel, subterranean burial chafts, fronted by a sunken enclosed forecourt with raised walls of modern stone and brick that follow the original forecourt conception. The tomb at one time was fronted by decorated door jambs and perhaps steps leading into the forecourt which are no longer is in evidence. Mond noted six burials including a shaft in the courtyard, a shaft in the transverse hall, and a sloping passage with steps that began before the statue niche. The exact location of the remaining three shafts is no longer known. Another burial was recently discovered in the northwest enclosure wall (Kampp Nr. -312-) that dates from a later period [15]. Mond, using the excavation methods of his day, only recorded a few small burial finds (small coffin, blue bead necklace, emerald lotus column amulet, scribe's staff, gilt-plaster fragments), and human remains (remains of a child in a small coffin) from the tomb. At least three burials appear to derive from the time of Menna: one in front of the Osiris scene, another in the forecourt, and the sloping passage. The sloping passage, in particular, could be the burial of Menna. As a structural member, recent research indicates the sloping passage begins to be used in private tombs already in the Middle Kingdom [16]. It is clear that the sloping passage dates to the original conception of the tomb, and the 26th dynasty gilt-plaster fragments found by Mond may date from a later reuse of the passage.

As noted by many scholars, the tomb of Menna has not been scientifically published. Little is known about Menna, other than his titles and some geneological information. He was an "Overseer of the Fields" and supervised the Cadastral survey, high positions in the 18th dynasty given the importance of grain in Egypt's barter economy. His daughters appear to have served the royal court. His wife Henuttawy figures prominently in the tomb and is one of a few women in the 18th dynasty to be represented with a scribal kit underneath her chair, an indication of her literacy [17]. Menna's representations and some of Henuttawy's show damnatio memoriae, a fate which did not befall his sons or his daughters.

Open to the public since the 1960s, the tomb of Menna is at the mercy of environmental forces, all of which have contributed to the deterioration and destabilization of the chapel paintings. To date there has been no systematic documentation of the previous conservation interventions. However, it is possible to trace the deterioration of the paintings and previous conservation interventions through comparisons between the original Robert Mond photos taken in 1914-1916, the series taken in the 1960s and 1970s ([14]) and the tomb chapel's present day condition. There appear to have been at least two significant conservation interventions, and probably a series of more recent on-going small interventions and running repairs. Given the sophistication of the painted decoration, conservation of the wall surface is essential to stabilize and preserve the chapel for future scholars and visitors.

The tomb of Menna is uniquely suited for the study of work process, not only in terms of procedure but also in terms of the time span in which the painting was achieved. On the BHNR (broad hall near right wall) substantial changes exist between the preliminary drawings and the final painting. The difference in style on some of the tomb walls suggests a long period of manufacture, perhaps done at several times over the reigns of Thutmose IV and Amenhotep III 


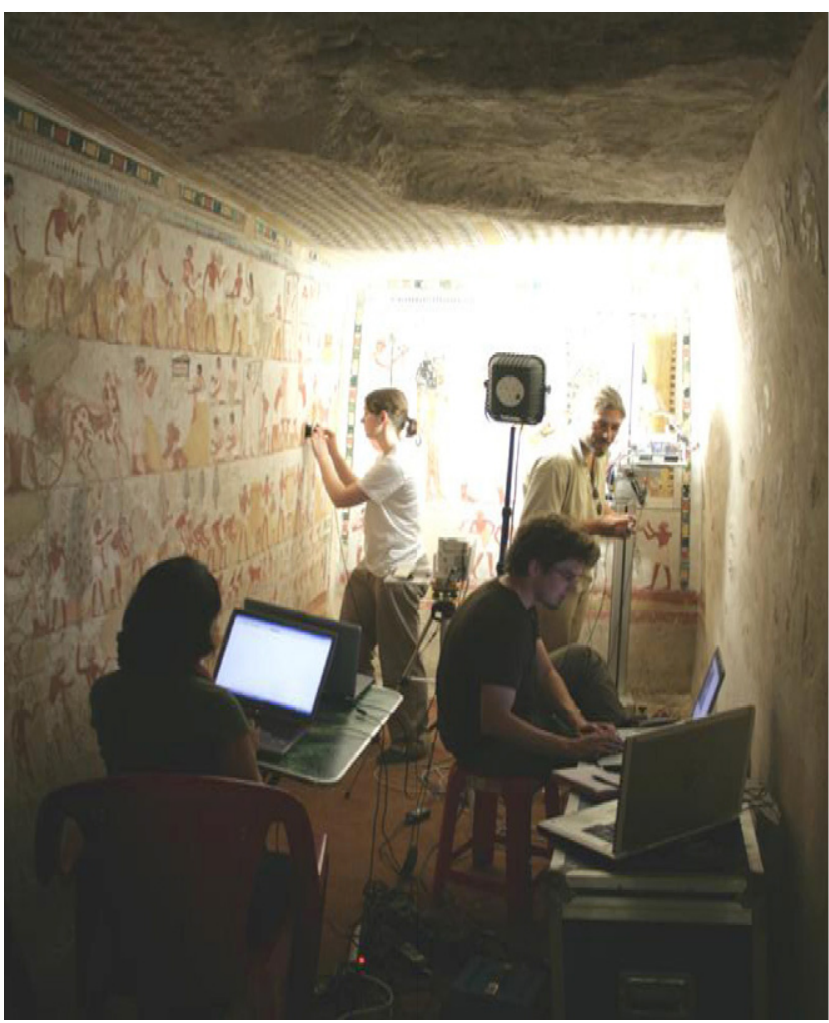

Fig. 3. Working conditions in the tomb: working with several, complementary analytical techniques in a relatively small area.

and the presence of a changing group of artists. Colour layering and mixing techniques in the tomb are particularly accomplished and study would reveal much about painting practices and the practices of specific artists [17-19].

\section{Experimental}

During November-December 2007, in a 5-week archaeometrical survey, several analytical instruments were brought to the site of Menna, in order to perform totally non-destructive investigations. Electrical power was foreseen through an external generator, working on petrol.

\subsection{Raman spectroscopy}

The instrument that has been used for this research has previously been described extensively [20,21]. The core of our mobile art analyser (MArtA) is a portable Raman imaging microscope (PRIM, Spectracode, West Lafeyette, IN, United States). It is based on a SpectraPro 150i f.15 spectrometer (Roper scientific/Princeton Instruments). These investigations have been performed by using the 600 groves $/ \mathrm{mm}$ dispersion grating. Laser power was adjusted up to a maximum of ca. $15 \mathrm{~mW}$ at the sample, to avoid all possible damage. By using a $785 \mathrm{~nm}$ laser, spectra were obtained between 200 and $2500 \mathrm{~cm}^{-1}$. A $6 \times$ objective lens has been used, allowing a working distance of ca. $5 \mathrm{~mm}$. The working area could be observed through a USB-controlled colour camera, incorporated into the probe head. During these experiments the probe head was mounted on an articulating arm, allowing the macropositioning in height and in the horizontal direction. Micropositioning and focusing was achieved through three manually controlled micropositioners (Thorlabs) with a travel of $2.5 \mathrm{~cm}$.

\subsection{XRF spectroscopy}

X-ray fluorescence is a non-destructive, multi-elemental, fast analysis technique. It can be applied in a non-vacuum environment, directly on the sample, without any preparation. The transportable system used was designed and realised at the IPNAS laboratory (ULg) [22]. The system includes a miniature X-ray tube from Moxtek which supplies the primary beam. The detector is a Peltier-cooled silicon drift detector (SDD) with a $10 \mathrm{~mm}^{2}$ active area. The data acquisition has been made through an home made electronic multichannel analyzer (MCA) measuring the energy and the intensity of the out-coming fluorescence radiation. The detector signal is amplified and analysed by this multichannel recorder, coupled to a micro-computer, running a program specially written for this application, which visualizes and analyses spectra obtained from the detector. The detection head, containing the detector, the X-ray tube and its power supply, is fixed on a movable platform, allowing an independent vertical and horizontal and forward and backward movement. All displacements are controlled by a small hand-held PDA (Palm) which exchanges data with microcontrollers embedded in the system providing a very precise positioning of the detector over a surface of many square meters. And points analysis positioning without touching the head detection or moving the whole system.

\subsection{Ultra-violet-visible and near infrared (NIR) spectroscopy}

We used a StellarNet UV, visible, and near infrared - InGaAs EPP2000C spectrometer provided with a CCD detector and working in the retrodiffusion mode. This instrument is fitted with an optical fibers probe which is set close $(4 \mathrm{~mm})$ to the sample surface at an angle of $45^{\circ}$ to avoid direct reflection. The probe includes six illuminating fibers and one (the center one) for the collection of the diffused light. With this setup, the analysed sample area is of the order of $4 \mathrm{~mm}^{2}$. Calibration is made with a Halon D65 white reference in exactly identical lightning conditions as for experimental samples. The absorbance spectrum and the colour parameters $\left(L^{*}\right.$, $\left.a^{*}, b^{*}\right)$ are subsequently obtained by software.

Visible spectroscopy gives two types of objective measurements of colours. The first concerns the spectra which depend on the reflection of the incident light by the studied material. These spectra are specific for each material, and allow approaching their nature. Also, this equipment indicates the values of colour using $L^{*} a^{*} b$ measurements, which is very useful for comparing different pigments and mixtures. The InGaAs spectrometer covers the NIR wavelength range from 0.9 to $1.7 \mu \mathrm{m}$. The InGaAs detector is a Sensors Unlimited linear photodiode array with 512 pixels.

\section{Results and discussion}

\subsection{Planning and selection of the measuring points}

The study started with a thorough visual inspection and photographical survey, in which all the walls in the tomb were photographed with visible, raking and UV light, as well as a detailed measurement of the dimensions of the tomb. Selection of the measuring points relies, on the one hand, on the possibilities and limits of each analytical technique and on the other hand the relevance to reach the aims of the study has to be taken into account. The selection was based on observations by the art-historians and conservators and was discussed thoroughly with the spectroscopists in the team. Moreover, where possible, the preliminary results of selection and planning of the points of analysis is vital, since the time that the team had access to the tomb was limited. Therefore, 

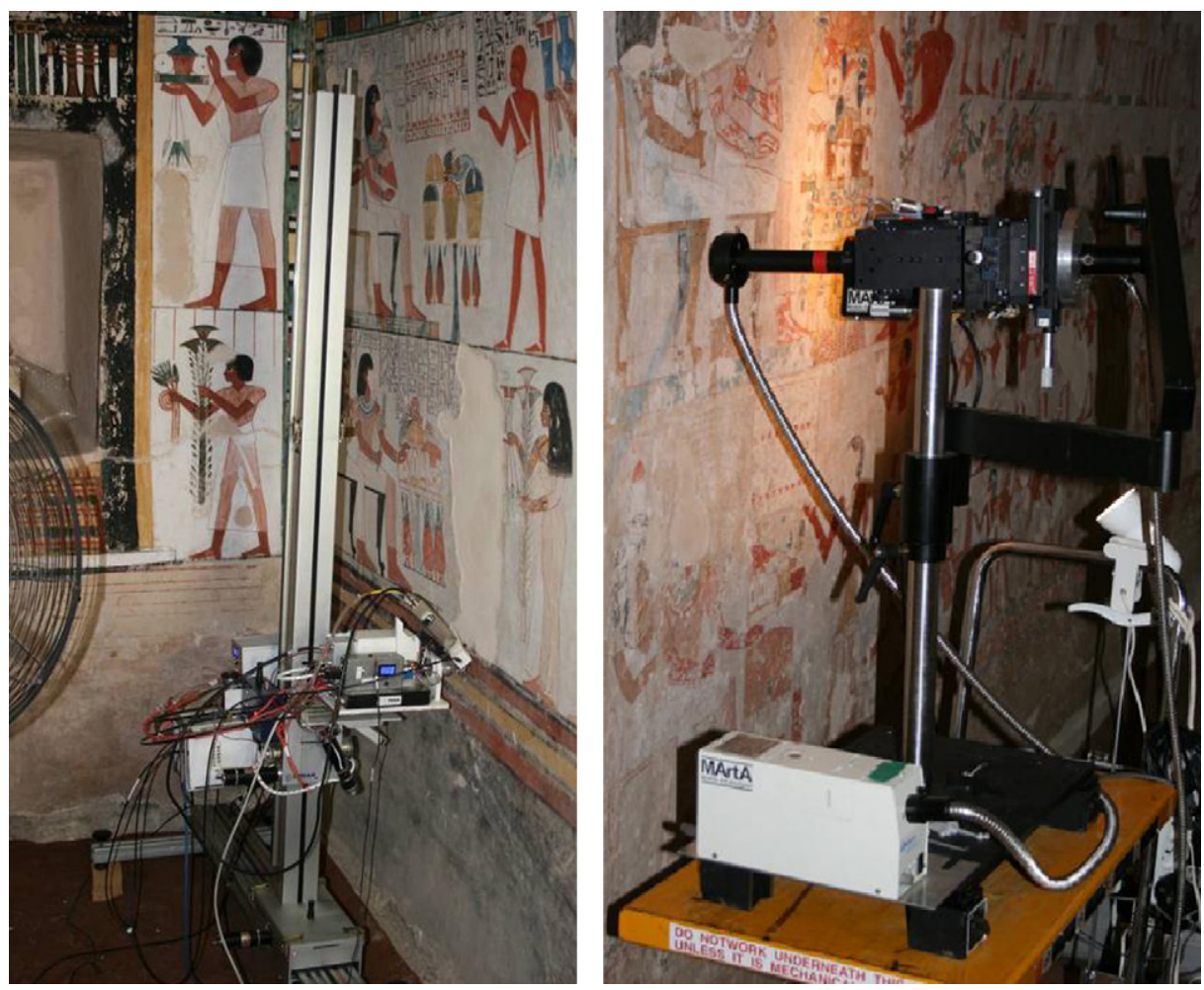

Fig. 4. Experimental set-up for XRF and for direct Raman analysis of the wall paintings.

the points were grouped, based on their neighbouring positions, in order to minimise the time needed to position the instrumentation. In order to work on exactly the same spot with the different techniques, it was important to mark the exact spot position, which was done in Photoshop. A problem that is related to this is that the spot size for the different techniques was different: diameters were ranging from ca. $0.5 \mathrm{~cm}$ (IR, UV-vis) to ca. $1 \mathrm{~mm}$ (XRF) and even ca. $100 \mathrm{~nm}$ (Raman spectroscopy).

\subsection{Set-up and experimental hazards}

Sampling - how small it might be - was not allowed in the tomb of Menna (TT69) and all equipment was brought into Egypt and to the site. Although designed for mobile use, transport of sensitive scientific equipment by plane, train and uneven, dusty, roads is not advisable-not to mention the transfer of the equipment from one transportation vehicle to the other. All analytical techniques were performed more or less simultaneously, on different spots in the tomb. Since space is limited, and some techniques have their own needs (e.g., visual examination requires light, Raman, near infrared, and UV-vis spectroscopies require darkness), careful planning of the working positions was vital. By using black cloth and wooden post, a screen was made, which could divide the tomb in to two parts. When darkness was required, the entrance door of the tomb had to be closed, which made the inside temperatures raise to ca. $40^{\circ} \mathrm{C}$-and reaching the limits that the instruments and computers could bear. The floor of the tomb is uneven, so wooden blocks and wedges were used to level the instrumentation.

Working in Egypt, on the border of the desert, inevitably implicates a dust problem. Dust accumulating inside the instrumentation, computers, and on the electronics caused severe problems. E.g. band broadening of XRF spectra can be attributed to this effect. Electrical power was delivered by a generator-but our instrumentation required grounding to prevent charge accu- mulation. Therefore, metal parts of the equipment were connected to survey nails, used by archaeologist during excavation. The effects of maybe not so gentle treatment during transportation, combined with harsh working conditions, caused major breakdown of the XRF instrumentation during the first 2 weeks of the archaeometrical campaign, requiring us to reorganise the work in the remaining time.

\subsection{Some results}

However, using both complementary in situ techniques, it was possible to identify several painting materials in the wall paintings.

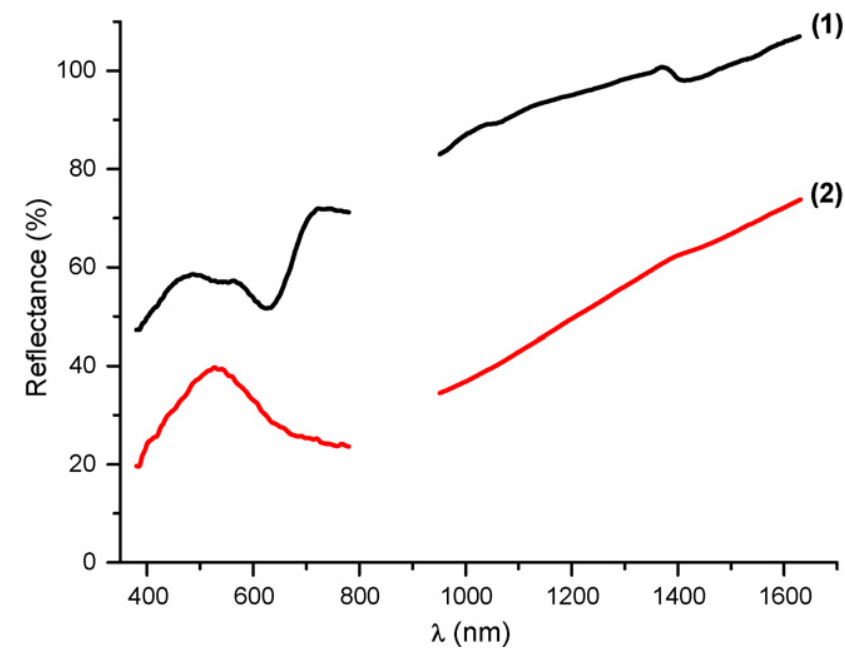

Fig. 5. Reflectance spectra of a blue (1) and a green (2) area, respectively, LHR0098 and BHNL0625, corresponding to Egyptian blue and Egyptian green, recorded in the UV-vis-NIR spectral region. 
Table 1 gives an overview of some of the pigments that were identified during this survey. The presence of certain key-elements in XRF investigations was indicative for the presence of specific pigments [23]. For instance, the presence of iron in some red areas reveals the use of iron oxide $\left(\mathrm{Fe}_{2} \mathrm{O}_{3}\right)$, which could be confirmed by Raman spectroscopy. One has to bear in mind that light elements $(Z<16)$ could not be detected, due to absorption by the detector window and the atmosphere. Moreover, it was not always possible to distinguish whether a certain element was present in the top (pigment) layer, rather than in an underlying layer or in both. The element Ca was omnipresent in all investigations: in some cases this originated from the surface layer where calcite $\left(\mathrm{CaCO}_{3}\right)$ or gypsum $\left(\mathrm{CaSO}_{4} \cdot 2 \mathrm{H}_{2} \mathrm{O}\right)$ - detected by Raman spectroscopy - are used as a pigment, but the ground layer, which is mainly composed of $\left(\mathrm{CaSO}_{4} \cdot 2 \mathrm{H}_{2} \mathrm{O}\right)$, is also detected by XRF. In some cases, the probe head could be tilted: an approach in which the relative intensities of the peaks from the surface layer towards those from underlying layers are enhanced. Finally, XRF is not able to discriminate between several pigments in mixtures, if these have the same keyelement (e.g., realgar and orpiment or hematite and goethite). The detection of the element sulphur was sometimes of help, but as the secondary X-rays of this element are relatively weak, it was not always straightforward how to interpret these results. Nevertheless, the quickness of this analysis allowed us to have an entire survey of the tomb, and to see the different possible mixtures of elemental composition to have a better understanding of the artists' palette and know-how.

Raman spectroscopy was strongly hampered by fluorescence, caused by the presence of paraloid B72 resin, which was applied during a previous undocumented conservation treatment. However, on some areas it was possible to obtain a weak Raman signal, along with the fluorescence signal. However, weak Raman scatterers, like goethite, could not be identified as such by Raman spectroscopy. By differentiating between the intense Raman bands, caused, respectively, by the symmetric $v\left(\mathrm{CO}_{3}{ }^{2-}\right)$ and $v\left(\mathrm{SO}_{4}{ }^{2-}\right)$ stretching vibrations, the distinction between calcite and gypsum could be made. Similarly, the difference between orpiment and realgar could as well be achieved-until now no pararealgar could be identified in these wall paintings.

One remarkable thing in these wall paintings is that the artists in some scenes deliberately used mixtures and transparency effects. Whereas XRF sometimes has problems in distinguishing between different layers, due to its better lateral resolution, Raman spectroscopy could differentiate between neighbouring pigments in the same layer.

UV-vis and near infrared spectroscopy add more information mainly by giving an objective measurement of colour and helping to detect organic materials.

This project will also help to evaluate the possibilities of these three techniques to obtain a global characterisation of pigments and mixtures, which is of real interest for fieldwork, since these are really portable equipments that could be easily included in future projects. These possibilities will be known after the data treatment.

Coupling UV-vis with XRF allows discriminating the different layers of the paintings. Indeed, XRF analyses give data from the global composition the pictorial layer. As vis spectroscopy gives information on the surface layer. Doing an identification of the surface pigments composition allows having a better idea of the overlaying of the pictorial material. This procedure needs further data treatment, but will certainly help for the interpretation of the artist's technique and organisation.

From the practical experience gained with the archaeometric survey in the tomb of Menna, it can be said that vis spectroscopy is an excellent method to objectively determine the colour from a certain area, but identifying pigments' mixtures with this technique sometimes is hampered. Among our first results we can state that by using visible spectroscopy it is possible to identify and differentiate red and yellow ochers, as well as between Egyptian blue and Egyptian green (Figs. 1-5). For Egyptian blue, two major absorption bands at about 560 and $628 \mathrm{~nm}$ [24].

Near Infrared retrodiffused spectroscopy helped to clearly identify the gypsum plaster: three typical absorption bands in the $1450-1550 \mathrm{~nm}$ region, which are evident in almost all of the spectra, are basically due to the water molecules of the gypsum layer.

However, the objective determination of the colour can be of great use when further processing of the data is required, e.g., when chemometric analysis of the XRF results is required. Compared to Raman spectroscopy, when using XRF a relatively high number of points can be analysed in a limited amount of time: positioning and focussing is relatively fast and because of the relatively large spot size it is not necessary to record several spectra on micrometers from each other. All this advantageous features make XRF a good method for the survey of the tomb, and to identify and characterise the artist's palette. Nevertheless its limits make necessary to be completed, for a certain number of points, with Raman by pinpointing the regions which might be of high interest for Raman spectroscopy-although fluorescence might hamper these investigations on some points.

\section{Conclusions}

For the first time, an extensive, multi-method archaeometrical approach was used to examine the Egyptian painting technique in the antique tomb of Menna (TT69, Theban Necropolis). For this research, only non-destructive techniques could be applied. Despite the harsh working conditions, that severely influenced the investigations, it was possible to identify the pigments that were applied in this tomb. This, combined with an extensive visual analysis, will form the basis for the description of the painting technique, as well for the study of the organisational aspects of the artists' workshops over the reigns of Thutmose IV and Amenhotep III.

\section{Acknowledgements}

The Tomb of Menna Project (TT69) is a sponsored project of Georgia State University under the direction of Melinda Hartwig, supervised by the Egyptian Antiquities Conservation Project-American Research Center in Egypt with funding from the United States Agency for International Development. Financial support of Interuniversity Attraction Poles Program - Belgian State Belgian Science Policy is greatly acknowledged.

\section{References}

[1] S. Pages-Camagna, S. Colinart, C. Coupry, J. Raman Spectrosc. 30 (4) (1999) 313-317.

[2] S. Pages-Camagna, S. Colinart, Archaeometry 45 (2003) 637-658.

[3] A.R. David, H.G.M. Edwards, D.W. Farwell, D.L.A. de Faria, Archaeometry 43 (2001) 461-473.

[4] H.G.M. Edwards, S.E.J. Villar, K.A. Eremin, J. Raman Spectrosc. 35 (8/9) (2004) 786-795.

[5] H.G.M. Edwards, S.E.J. Villar, A.R. David, D.L.A. de Faria, Anal. Chim. Acta 503 (2) (2004) 223-233.

[6] J. Ambers, J. Raman Spectrosc. 35 (8/9) (2004) 768-773.

[7] V. Daniels, B. Leach, Stud. Conserv. 49 (2) (2004) 73-84.

[8] P. Vandenabeele, A. von Bohlen, L. Moens, R. Klockenkämper, F. Joukes, G. Dewispelaere, Anal. Lett. 33 (15) (2000) 3315-3332.

[9] P. Vandenabeele, J. Tite, L. Moens, Anal. Bioanal. Chem. 387 (2007) 813-819.

[10] K. Leterme, et al., Development of a new visual analysis protocol for the methodological examination of Egyptian funeral wall paintings.

[11] R. Mond, Report of work in the Gebel esh-Sheikh Abd-el-Kurneh at Thebes, January to March 1903, ASAE 5 (1904) 102-103.

[12] R. Mond, Report of work in the necropolis of Thebes during the winter of 1903-1904, ASAE 6 (1905) 88. 
[13] C. Cambell, Two Theban Princes Kha-em-uast \& Amen-Khepeshf, sons of Rameses III; Menna, a Land-Steward and their tombs, London, 1910, pp. 85-106.

[14] M. Maher-Taha, Le tombeau de Menna [TT. No. 69], series editor, Zahi Hawass, Cairo, CEDAE, 2002.

[15] F. Kampp, Die thebanische Nekropole: Zum Wandel des Grabgedankens von der XVIII. bis zur XX. Dynastie, I, Theben XIII, Mainz (1996) 294-297.

[16] F. Kampp, Die thebanische Nekropole: Zum Wandel des Grabgedankens von der XVIII. bis zur XX. Dynastie, I, Theben XIII, Mainz (1996) 84-86.

[17] Betsy M. Bryan, Evidence for female literacy from Theban tombs of the New Kingdom, BES 6 (1984) 17-32.

[18] V. Davies (Ed.), Colour and Painting in Ancient Egypt, London, 2001.

[19] P.T. Nicholson, I. Shaw, Ancient Egyptian Materials and Technology, Cambridge, 2000.
[20] P. Vandenabeele, T.L. Weis, E.R. Grant, L. Moens, Anal. Bioanal. Chem. 379(2004) 137-142.

[21] P. Vandenabeele, K. Lambert, S. Matthys, W. Schudel, A. Bergmans, L. Moens, Anal. Bioanal. Chem. 383 (2005) 707-712.

[22] F.-P. Hocquet, H.-P. Garnir, A. Marchal, M. Clar, C. Oger, D. Strivay, X-ray Spectrom. 37 (2008) 304-308.

[23] R. Garcia Moreno, H. Calvo del Castillo, P. Vandenabeele, Preliminary examination of natural Egyptian painting materials with Raman spectroscopy, X-ray fluorescence and X-ray diffraction. Proceedings of IV Conference of Raman Spectroscopy applied to Art and Archaeology, Modena, Italy, 2007.

[24] P. Mirti, L. Appolonia, A. Casoli, R.P. Ferrari, E. Laurenti, A. Amisano, G. Chiari, Spectrochim. Acta 51A (1995) 439-446. 